\title{
АЛГОРИТМ ДІАГНОСТИЧНОГО ОБСТЕЖЕННЯ ПОТЕРПІЛИХ 3 ПРИВОДУ ПОЛІТРАВМИ НА ТЛІ ОЖИРІННЯ
}

\author{
С. Д. Хіміч ${ }^{1}$, О. М. Чемерис ${ }^{2}$
}

${ }^{1}$ Львівський національний медичний університет імені Данила Галицького,

${ }^{2}$ Вінницький національний медичний університет імені М. І. Пирогова

\section{ALGORITHM OF DIAGNOSTIC EXAMINATION OF THE INJURED PERSONS FOR POLYTRAUMA ON THE OBESITY BACKGROUND}

\author{
S. D. Khimich ${ }^{1}$, O. M. Chemerys ${ }^{2}$ \\ ${ }^{1}$ Lviv National Medical University named after Danylo Galytskyi, \\ ${ }^{2}$ Vinnytsya National Medical University named after M.I. Pyrogov
}

\begin{abstract}
Реферат
Мета роботи. Розробити діагностичний алгоритм обстеження потерпілих з політравмою на тлі ожиріння з огляду на особливості перебігу травматичної хвороби та ступеня ожиріння.

Матеріали і методи. Проаналізовані результати спостереження 54 потерпілих з політравмою, яких лікували в хірургічному відділенні Комунальної 8-ї міської клінічної лікарні Львова у 2013 - 2016 рр.

Результати. Тривалість виконання діагностичних маніпуляцій у пацієнтів при ожирінні II - III ступеня збільшувалась у середньому на $(28 \pm 1,4)$ хв, що пов'язане з технічними труднощами відбору біологічного матеріалу, необхідністю частого повторення обстеження з метою уточнення діагнозу чи проведення додаткових інвазивних маніпуляцій. Пошкодження у потерпілих при політравмі на тлі ожиріння значно тяжчі, ніж за нормальної маси тіла, що зумовлене порушенням системи метаболізму, морфологічними проявами дезорганізації, розростанням сполучної тканини з подальшою стромально-судинною дистрофрією.

Висновки. Клінічна апробація запропонованого алгоритму свідчила, що ця тактика дозволяла прецизійно оцінити тяжкість травми у потерпілих на тлі ожиріння, обґрунтувати своєчасність обрання адекватних діагностично-тактичних рішень, зокрема, застосування інвазивних методик.

Ключові слова: політравма; ожиріння; діагностичний алгоритм.

Abstract

Objective. To elaborate diagnostic algorithm of examination of the injured persons, suffering polytrauma, based on obesity, taking into account peculiarities of the traumatic disease and the obesity degree.

Materials and methods. Results of observation of 54 injured persons, suffering polytrauma, treated in Surgical Department of the Lviv Commune 8-th Municipal Clinical Hospital in 2013 - 2016 yrs, were analyzed.

Results. Duration of the diagnostic procedures performance in patients, suffering obesity stages II - III, is enhanced by ( $28 \pm 1.4)$ min at average, what is connected with technical difficulties in the biological material taking, necessity of frequent reexamination for the diagnosis detalization or doing additional invasive procedures. The injuries in polytrauma patients on the obesity background are significantly more severe, than in normal body mass, because of occurrence of the metabolism system disorder, morphological signs of disorganization, and growing of connective tissue with further stromal-vascular dystrophy.

Conclusion. Clinical approbation of the algorithm have witnessed, that the tactics proposed have permitted to estimate the trauma severity on background of obesity precisely, and to substantiate a timely choosing of adequate diagnostic-tactical decisions, including application of invasive procedures.

Keywords: polytrauma; obesity; diagnostic algorithm.
\end{abstract}

Множинні пошкодження тіла $€$ домінуючою причиною смерті потерпілих віком від 1 до 44 років, за частотою поступається лише онкологічним та оклюзійним атеросклеротичним захворюванням в усіх вікових групах. За даними досліджень, хірург політравми відіграє ключову роль в лікуванні потерпілих з приводу ізольованої, поєднаної та комбінованої травми на госпітальному етапі. Він є членом команди, що складається з багатьох фахівців, в тому числі реаніматологів, травматологів, нейрохірургів, інших суміжних спеціалістів, кожний з яких має бути ознайомлений з основами й за- гальними принципами організації та надання невідкладної допомоги потерпілим при політравмі [1 - 3].

Особливого підходу потребують потерпілі 3 надмірною масою тіла та ожирінням різного ступеня. Так, у потерпілих при ожирінні клінічний перебіг травматичної хвороби більш тяжкий, ніж за нормальної маси тіла $[3,4]$. Незважаючи на меншу тяжкість закритої черепно-мозкової травми, потерпілі довше перебувають у лікарні внаслідок збільшення тривалості штучної вентиляції легень у середньому на 2 - 3 доби, частішого формування гострого респіраторного дистрес-синдрому, виникнен- ня інфаркту міокарда і ниркової недостатності, включаючи фактор супутніх захворювань і впливу різних моделей травми [5, 6]. Також слід наголосити на труднощах догляду за такими пацієнтами, що може спричинити виникнення гнійно-септичних ускладнень i, як наслідок, тенденції до більш високої смертності пацієнтів за індексу маси тіла (IMT) $35,3-41,9 \kappa \Gamma / \mathrm{M}^{2}$.

Негативний вплив ожиріння на результати лікування потерпілих 3 приводу політравми має істотні наслідки для всієї системи охорони здоров'я, адже, у таких хворих більші витрати ресурсів для досягнення 
такого самого клінічного результату, ніж у пацієнтів за нормальної маси тіла. Для покращення наслідків лікування потерпілих з ожирінням ми розробили діагностичний алгоритм з огляду на діагностичну цінність та тривалість додаткових методів обстеження [4, 7].

Мета дослідження: розробити діагностичний алгоритм обстеження потерпілих з політравмою на тлі ожиріння 3 огляду на особливості перебігу травматичної хвороби та ступінь ожиріння.

\section{МАТЕРІАЛИ I МЕТОДИ ДОСЛІДЖЕННЯ}

Проаналізовані результати спостереження 54 потерпілих з політравмою, яких лікували у хірургічному відділенні Комунальної 8-ї міської клінічної лікарні Львова у 2013 2016 рр. У 35 (64,8\%) потерпілих виявлена поєднана тупа травма грудей та живота, у 19 (35,2\%) - переломи кісток таза чи кінцівок. Вік хворих від 18 до 87 років, у середньому (41,8 $\pm 1,2)$ року; чоловіків було 38 (70,4\%), жінок - 46 (29,6\%), працездатного віку $-41(75,9 \%)$.

Залежно від величини IMT потерпілі розподілені на три клінічні групи. В 11 хворих (І група) відзначено нормальну масу тіла (IMT 24,9 кг/м²); у 29 (II група) - надмірну масу тіла та ожиріння I ступеня (IMT 26,2 - 34,2 кг $/ \mathrm{M}^{2}$ ); у 14 (III група) ожиріння II -

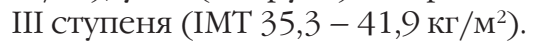

Потерпілі госпіталізовані у строки від 15 хв до 6 год, у середньому $(1,5 \pm$ $1,4)$ год 3 моменту травми. За обставинами травми переважали дорожно-транспортна пригода (водій, пасажир або пішохід) - у 27 (50\%) потерпілих, падіння з висоти $3-5$ м - у 19 (35,2\%), побиття - у 8 (14,8\%).

Обстеження проводили за загальноприйнятими і локальними протоколами, що включали аналіз скарг, анамнезу захворювання та життя, клінічних проявів на різних етапах лікування потерпілого - догоспітальному та стаціонарному, особливості травмуючого чинника.

\section{РЕЗУЛЬТАТИ}

Усіх потерпілих після госпіталізації відразу оглядали хірург, реаніматолог, нейрохірург, травматолог, у 87,5\% спостережень до команди лікарів долучали кардіолога чи тера- певта. Після отримання попередніх даних об'єктивного обстеження хірургом визначали перелік і черговість додаткових методів діагностики.

Під час первинного огляду оцінювали прохідність дихальних шляхів, визначали параметри гемодинаміки, усували безпосередні загрозливі для життя стани. Наступним етапом збирали анамнез, як правило, протягом кількох хвилин. Під час зміни стану пацієнта, зокрема, вітальних ознак, психічного статусу, повторно проводили опитування 3 метою виявлення потенційного загрозливих для життя станів. Так, наявність задишки, спонтанного дихання, хропіння могла свідчити про часткову обструкцію дихальних шляхів; ослаблення голосу, крепітація, наявність підшкірної емфіземи - про травму гортані чи закриту травму грудей. Таким чином, будьяка безпосередня загроза для життя, a саме, напружений пневмоторакс - у 13 (24,1\%) хворих, масивний гемоторакс - у 12 (22,2\%) була негайно ідентифікована і, відповідно, швидко усунена шляхом дренування плевральних порожнин за Бюлау. Моніторинг пульсоксиметрії для визначення оксигенації периферійної крові давав більш точні результати за нормальної маси тіла й ожиріння І ступеня - у 40 (74,1\%) хворих, проте, був практично неінформативним у 14 (25,9\%) хворих при ожирінні II - III ступеня. Це можна пояснити порушеннями мікроциркуляції, зумовленими супутніми захворюваннями, збільшенням тривалості діагностичних маніпуляцій.

Зазначені ускладнення виявлені у 12 (85,7\%) хворих на ожиріння (III група), та у 24 (60\%) пацієнтів I і II груп.

Лабораторні дослідження проведені всім хворим. Результати аналізів потерпілих I і II груп отримували у середньому - через $(27,3 \pm 1,2)$ хв, III групи - через $(38,5 \pm 1,6)$ хв у зв'язку 3 технічними труднощами катетеризації магістральних судин у 8 (14,8\%) хворих.

Наступним етапом у 29 (53,7\%) потерпілих, за стабільних показників гемодинаміки, яким не показані невідкладні втручання, проводили скринінгову рентгенографію черепа, грудної клітки, таза. Обстеження здійснювали в умовах операційної 3 використанням переносного рентген апарата. У положенні пацієнтів лежачи зменшувалася діагностична цінність обстеження щодо виявлення плевро-легеневих ускладнень, зокрема, рівня рідини у плевральній порожнині (s=42,6\%, f = 59,1\%, p > 0,03), особливо у потерпілих з ожирінням II-III ступеня, у яких ці показники були ще меншими ( $\mathrm{s}=21,3 \%, \mathrm{f}$ $=32,4 \%, \mathrm{p}>0,04) .3$ метою верифікації діагнозу у 92,9\% потерпілих ціеї групи неодноразово проводили повторне обстеження, що збільшувало його тривалість до $(19,3 \pm 1,4)$ хв. Такі результати були зумовлені як суб'єктивними причинами - відсутністю необхідних режимів апарата, так і об'єктивними - товщиною підшкірного прошарку, зменшенням еластичності та щільності тканин, тому для уточнення діагнозу виконували торакоцентез, що у 92,8\% хворих дало можливість верифікувати наявність повітря чи крові у плевральній порожнині. Рентгенографія кісток черепа, таза і кінцівок у 88,8\% потерпілих дала можливість діагностувати переломи різної локалізації.

Забій легень діагностували шляхом візуалізації вогнищ інфільтраціï різного розміру 3 посиленням легеневого рисунка, неоднорідної структури, без чітких контурів. Найчастіше зміни виявляли в проекції перелому ребер. Відсутність контуру куполу діафрагми 3 дислокацією органів черевної порожнини прямо свідчила про розрив діафрагми.

Діагностика тупої травми живота часто $є$ проблемою навіть для досвідчених хірургів. Крім об’єктивного клінічного обстеження, застосовували ультразвукове дослідження (УЗД) в режимі FAST (Focused Assessment with Sonography for Trauma) і діагностичний перитонеальний лаваж (ДПЛ). УЗД моніторинг давав можливість швидко виявити вільну рідину у лівому піддіафрагмальному заглибленні навколо селезінки, кишені Морисона чи порожнині малого таза, що у 21 (72,4\%) хворого було показанням до виконання невідкладного оперативного втручання; діагностувати пошкодження нирки і заочеревинну гематому, ознаками чого були неоднорідні гомогенні затемнення 3 можливим відтис- 
канням нирки чи наявність рідини в ії ложі. Тривалість обстеження у середньому $(6,4 \pm 1,3)$ хв. Виявлення вільної рідини у лівій надчеревній ділянці свідчило про розрив селезінки - в 11 (52,3\%) або ії повний відрив - у 2 (9,5\%) потерпілих; у кишені Морисона або правій бічній ділянці - про травму печінки у 8 (38,2\%).

У 8 (27,6\%) пацієнтів при ожирінні II - III ступеня заключення УЗД було сумнівним, їм проведений ДПЛ. Перевагами методу є швидке виявлення внутрішньочеревної кровотечі, можливість аналізу одержаної рідини для виявлення вмісту кишечнику, жовчі чи сечі. Для диференційної діагностики внутрішньочеревної кровотечі та перфузії рідкої частини крові в черевну порожнину з заочеревинного простору порівнювали величину гематокриту в периферійному судинному руслі та аспірованій з черевної порожнини рідини. Суттєву різницю величини гематокриту трактували як наявність заочеревинної гематоми у 3 (10,3\%) хворих. Наявність жовчі визначали шляхом проведення реакції з йодом на білірубін - у 4 (13,8\%) пацієнтів, сечі - реакції з уреазою - в 1 (3,4\%). На підставі аналізу цих даних, 5 (17,2\%) хворих відразу оперовані, підтверджене пошкодження печінки і сечового міхура. Недоліком ДПЛ є його інвазивність, що потребувало більших витрат часу, у середньому (13 \pm $1,7) \mathrm{XB}$.

Комп'ютерна томографія (КТ) проведена у 9 (16,7\%) потерпілих за стабільних показників гемодинаміки. Перевагою методу є можливість одночасної візуалізації зображення усіх органів і тканин, вивчення їх контурів і структури, основним не-

\section{ЛITEPATYPA/REFERENCES}

1. Haiko HV, Derkach RV. Analiz prychyn i faktoriv, shcho zumovliuiut smertnist postrazhdalykh iz travmamy oporno-rukhovoho aparatu, otrymanymy pid chas DTP. Nauka i praktyka: mizhvidomchyi medychnyi zhurnal. 2014;(1):82-6. [In Ukrainian].

2. Khyzhniak AA, Dubivska SS, Veklych IA. uporiadnyky. Politravma: metodychni vkazivky zi spetsialnosti «Medytsyna nevidkladnykh staniv» dlia pidhotovky likariv-interniv, slukhachiv peredatestatsiinykh tsykliv. Kharkiv:KhNMU; 2014. 28 c. [In Ukrainian].

3. Brown CVR, Neville AL, Rhee P, et al. The impact of obesity on the outcomes of 1,153 critically injured blunt trauma patients. J TraumaInjury Infection \& Critical Care. 2005;59:1048-51.

4. Hur'iev SO, Berezka MI, Soloviov OS, ta in. Politravma yak medykosotsialna problema (ryzyk-oriientovanyi pidkhid). Medytsyna sohodni i zavtra.2012;1(54):28-31. [In Ukrainian].
Негативний вплив ожиріння на результати діагностики й лікування має істотні наслідки для всієї практичної медицини, оскільки для таких пацієнтів потрібні більші витрати робочої сили, зокрема, більша кількість молодшого і середнього медичного персоналу для їх переміщення й догляду, більша тривалість роботи приміщення через складність проведення будь-яких обстежень чи втручань [10].

Слід зазначити, що діагностична точність деяких візуалізаційних методів дослідження у постраждалих при політравмі знижується прямо пропорційно ступеню ожиріння: чим він більший, тим менша достовірність діагностичних прийомів. Це зумовлює необхідність частішого використання інвазивних методик (плевральна пункція, ДПл), що, 3 одного боку, покращує верифікацію пошкодження, 3 іншого, провокуе виникнення ускладнень, пов'язаних як з їх виконанням, так і втручанням у порожнини організму.

\section{висновки}

1. Запропонований алгоритм обстеження потерпілих при політравмі передбачає їх первинний розподіл залежно від IMT, що формує основи для комплексного диференційованого підходу до обстеження пацієнтів з ожирінням.

2. Клінічна апробація алгоритму свідчила, що така тактика дозволяє прецизійно оцінити тяжкість травми у потерпілих на тлі ожиріння, обгрунтовує своєчасність обрання адекватних діагностично-тактичних рішень, зокрема, щодо застосування інвазивних методик.
5. Buschmann CT, Gahr P, Tsokos M, et al. Clinical diagnosis versus autopsy findings in polytrauma fatalities. Scand J Trauma Resusc Emerg Med. 2010;18(1):55-61.

6. Gebhard F, Huber-Lang M. Polytrauma: pathophysiology and management principles. Langenbecks Arch Surg. 2008;393(6):825-31.

7. Karwan K. Evaluation of patients with polytrauma treated in the emergency department. Pol Merkur Lekarski. 2009;27(160):296-301.

8. Modica MJ, Kanal KM, Gunn ML. The obese emergency patient: imaging challenges and solutions. Radiographics. 2011;31(3):811-23.

9. Advanced trauma life support for doctors: instructor course manual; 6th ed. Chicago: American College of Surgeons Committee on Trauma; 1997. $863 \mathrm{p}$.

10. Sturm R. Increases in clinically severe obesity in the United States 1986 -2000. Arch Intern Med. 2003;163(18):2146-8. 